\title{
Prevalence of Gluten-Related Disorders in Asia-Pacific Region: A Systematic Review
}

\author{
Sara Ashtari ${ }^{1}$, Mohamad Amin Pourhoseingholi ${ }^{1}$, Kamran Rostami ${ }^{2}$, Hamid Asadzadeh Aghdaei ${ }^{1}$, Mohammad \\ Rostami-Nejad ${ }^{3 *}$, Luca Busani ${ }^{4}$, Mostafa Rezaei Tavirani ${ }^{5}$, Mohammad Reza Zali ${ }^{1}$
}

1) Gastroenterology and

Liver Diseases Research

Center, Research Institute for

Gastroenterology and Liver

Diseases, Shahid Beheshti

University of Medical Sciences,

Tehran, Iran

2) Departments of

Gastroenterology, Mid Centra

DHB, Palmerston Hospital,

Palmerston North,

New Zealand

3) Basic and Molecular

Epidemiology of

Gastrointestinal Disorders

Research Center, Research

Institute for Gastroenterology

and Liver Diseases, Shahid

Beheshti University of Medical

Sciences, Tehran, Iran

4) Department of Infectious

Diseases, Istituto Superiore di

Sanità, Roma, Italy

5) Proteomics Research

Center, Faculty of Paramedical

Sciences, Shahid Beheshti

University of Medical Sciences, Tehran, Iran

Address for correspondence: Mohammad Rostami-Nejad Basic and Molecular Epidemiology of Gastrointestinal Disorders Research Center, Research Institute for Gastroenterology and Liver Diseases, Shahid Beheshti University of Medical Sciences, Tehran, Iran.

m.rostamii@gmail.com

\section{ABSTRACT}

Background \& Aims: The epidemiology of gluten-related disorders (GRDs) is still an open field to be explored. We conducted this systematic review based on the current epidemiology knowledge of GRDs, focusing on the changing prevalence of GRDs reported in the Asia-Pacific region.

Methods: We searched Medline, PubMed, Scopus, Web of Science and Cochrane database with the following MeSH terms and keywords: celiac disease (CD), wheat allergy (WA), non-celiac gluten sensitivity (NCGS), dermatitis herpetiformis (DH) and gluten ataxia (GA) and the prevalence studies published from January 1991 to January 2018. Each article was cross-referenced with "Asia-Pacific region" and countries in this region such as Australia, New Zealand, India, Pakistan, Turkey, Iran and others.

Results: We included 66 studies, which reported the prevalence of GRDs in the Asia-Pacific region. Prevalence of celiac disease was $0.32 \%-1.41 \%$ in healthy children and $0.05 \%-1.22 \%$ in the adult population, while the prevalence in the high risk population was higher (0.6\%-11.8\%). Previous studies have shown a very low incidence of dermatitis herpetiformis $(\mathrm{DH})(<0.001 \%)$ and gluten ataxia $(\mathrm{GA})$ in this area. Few studies on NCGS outbreaks have been found in this area due to the lack of specific diagnostic biomarkers. Wheat allergy (WA), although uncommon in most Asian-Pacific countries, is the most common cause of anaphylaxis in this region. Conclusion: The results of this systematic review suggest the need to plan further proper epidemiological studies in order to understand the natural history of GRDs and to assess its burden on health systems.

Key words: gluten-related disorders - celiac disease - non-celiac gluten sensitivity - wheat allergy.

Abbreviations: AGA: anti-gliadin antibody; CD: celiac disease; DGP: deamidated gliadin peptides; DH: dermatitis herpetiformis; EMA: anti-endomysial antibodies; GA: gluten ataxia; GRDs: gluten-related disorders; IBS: irritable bowel syndrome; NCGS: non-celiac gluten sensitivity; SEIBDs: sub-epidermal immunobullous disorders; t-TG: tissue transglutaminase; WA: wheat allergy.

\section{INTRODUCTION}

Gluten-related disorders (GRDs) areknown as an epidemicrelated phenomenon that affects many people worldwide. In the 1980s, classification of GRDs was very simple, because celiac disease (CD) and dermatitis herpetiformis $(\mathrm{DH})$ were the only known diseases with a welldocumented role of gluten in their pathogenesis. More recently, gluten and other proteins have been recognized as a possible cause of wheat allergy (WA) [1]. In addition, the large number of patients with intestinal and extra-intestinal symptoms who are sensitive to dietary gluten without evidence of CD or WA, has contributed to the identification of a new gluten-related syndrome defined as non-celiac gluten sensitivity (NCGS) [2]. Therefore, the spectrum of GRDs covers a wide range from gastroenterology to allergy and from neurology to dermatology [3]. The classification of GRDs is presented in Fig. 1. Within the large family of GRDs, each gluten-related disorder exhibits a unique pathophysiological response to gluten ingestion, though there may be a significant overlap in clinical presentations. This overlap makes diagnosis difficult, particularly in the case of NCGS. As a result, different priorities and diagnostic tools are required for different situations.

Gluten-related disorders and questions surrounding these associations have recently attracted attention due to the high prevalence of undiagnosed cases with a large number of symptoms and complications inside and outside the small 


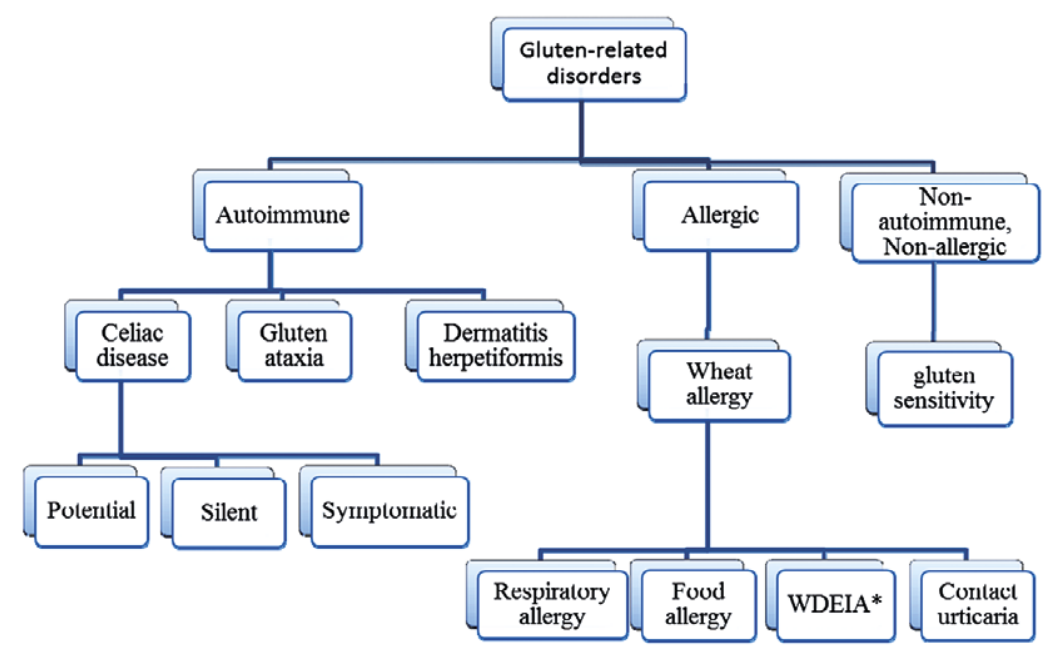

Fig.1. Classification of gluten related disorders according to the consensus conference on gluten related disorders held in February 2011[3]. *WDEIA: wheat-dependent exercise induced anaphylaxis.

intestine. Moreover, because of the development of sensitive and specific serological tests for the diagnosis of GRDs, the prevalence of the diseases has changed. Their true prevalence is underestimated and there is little information available regarding the prevalence of GRDs in the Asia-Pacific region. Therefore, we conducted a systematic review to evaluate the data concerning the epidemiology of GRDs, focusing on the changing of the reported GRDs prevalence in this region.

\section{METHODS}

We developed a protocol, including eligibility criteria, search strategies, a criteria for study selection and methods for extracting data according to the Preferred Reporting Items for Systematic Review and Meta-Analysis (PRISMA) guidelines [4].

\section{Search methods}

Previously published articles indexed in Medline, PubMed, Scopus, Web of Science and Cochrane database were searched using the following $\mathrm{MeSH}$ terms and keywords "prevalence AND gluten-related disorders", "prevalence AND Celiac disease", "prevalence AND Wheat allergy", "prevalence AND non-celiac gluten sensitivity", "prevalence AND dermatitis herpetiformis" and "prevalence AND gluten ataxia". Each one was cross-referenced with "Asia-Pacific region" and countries in this region such as Australia, New Zealand, India, Pakistan, Turkey, Iran and others. As the European Society for Pediatric Gastroenterology, Hepatology and Nutrition (ESPGHAN) released the first guideline for diagnosis of CD in 1990 [5], we considered this year as a dividing year for well-defined diagnostic criteria for CD and other gluten-related disorder. Therefore, all relevant published articles from January 1991 to January 2018 were included in this systematic review. Searching was carried out in the English language and those studies without access to the full text were not included in this review. Moreover, conferences related to GRDs and the references lists of studies were also assessed to include further appropriate articles. Figure 2 shows the flowchart of selecting the studies based on PRISMA guidelines.

\section{Inclusion criteria}

All the studies reporting the prevalence of at least one of GRDs in the general population in Asia-Pacific region were screened. For the adult population, we included studies that reported the prevalence in general and/or high-risk population based on celiac-specific serological tests [such as anti-tissue transglutaminase (t-TG) antibodies, antiendomysial antibodies (EMA) and deamidated gliadin peptides (DGP) antibodies] with confirmation of villous flattening at duodenum biopsies, according to the Marsh classification [6]. In children, guidelines allow the diagnosis of CD without endoscopy if $\mathrm{t}-\mathrm{TG}$ levels are increased more than 10x the upper normal limits. [7]. For DH, we included studies that reported the prevalence based on serological markers and duodenal biopsy. For gluten ataxia (GA) the biopsy was not necessary for the diagnosis. To assess the prevalence of WA we included studies that used wheat specific IgE or skin prick test (SPT), without duodenal biopsy. To investigate the status of NCGS in Asian-Pacific countries according to the Salerno criteria [8], all double-blind randomized placebo controlled trials (DBRPCT) that performed the gluten re-challenge in suspected NCGS patients were considered.

\section{Exclusion criteria}

The exclusion criteria were: (a) studies documenting the prevalence based on self-reporting database or hospital registries; (b) adult population studies reporting only the sero-prevalence of $\mathrm{CD}$; (c) studies reporting the $\mathrm{CD}$ prevalence only by anti-gliadin antibody (AGA) marker even with biopsy, because AGA is no longer recommended as a sensitive and specificity screening test for CD [7] (however, studies were included if AGA was used in combination with other celiacspecific serological tests); (d) case reports, case series and letters to the Editor; (e) studies without access to the full text and those with unclear results. 




Fig. 2. PRISMA flowchart of selecting the studies

\section{Study selection}

Two authors (S.A. and M.A.P.) performed the literature search, reviewed all the full texts, and individually evaluated the articles based on pre-decided inclusion and exclusion criteria. Disagreements between the two authors were resolved by discussion. If disagreements persisted, a third author (M.R.N.) reviewed the study and made the final decision. To increase the quality of the review, a blind method was used, hiding the journal and the author names.

\section{Data extraction}

Information extracted from each study included: name of the first author, year of publication, country of origin, number of included patients and their median age, type and design of the study, diagnosis of GRDs (serological markers and/ or duodenal biopsy), diagnosis of NCGS, duration of GFDs, outcome measure (prevalence \%).

\section{RESULTS}

Based on our inclusion criteria, 66 articles in the English language from January 1991 to January 2018, which reported the prevalence of at least one of the GRDs in Asia-Pacific region, were chosen for this study, that included 43 articles on CD, 6 on DH, 3 on GA, 4 on NCGS and 10 on WA.

\section{Celiac Disease (CD)}

We found 19 studies reporting the prevalence of $\mathrm{CD}$ in healthy and and 24 studies in high-risk population in 11 AsianPacific countries; New Zealand, Australia, Turkey, India, Iran, Israel, Saudi-Arabia, Kuwait, Oman, China and Japan. Data are synthetized in Table I [9-26]. Prevalence of CD ranged from $0.32 \%$ to $1.41 \%$ in healthy children and from $0.05 \%$ to $1.22 \%$ in adults.

The prevalence of CD is higher in some groups of patients, having a positive family history of $C D$, insulin dependent diabetes mellitus type 1 (DM1), chronic diarrhea, autoimmune thyroiditis, inflammatory bowel diseases (IBD), irritable bowel syndrome (IBS), Down syndrome (DS), Turner syndrome (TS) and also in dyspeptic patients. For these categories, serological and biopsy screening is necessary $[27,28]$. Data about the prevalence of GRDs in these high risk groups of patients are reported in Table II [29-52]. The reported ranges of $\mathrm{CD}$ prevalence were from $1 \%$ to $11.8 \%$ in high-risk children and $2.1 \%$ to $5.9 \%$ in high-risk adults. A study by Fukunaga et al. showed that the presence of CD in the healthy Japanese population was low at $0.05 \%$ and was rarely found in patients with unexplained chronic abdominal symptoms (2.1\%) [52].

\section{Dermatitis herpetiformis (DH)}

In the Asia-Pacific region, $\mathrm{DH}$ is very rare and only a few studies reported the prevalence of $\mathrm{DH}$ in this area, presented in Table III [53-58].

\section{Gluten ataxia (GA)}

There are comparatively fewer reports on GA in this region (Table III) [58-61].

Non-celiac gluten sensitivity (NCGS)

Few studies reported the prevalence of NCGS in AsiaPacific region (Table IV) [62-67]. 
Table I. Prevalence of celiac disease among the healthy population in Asian-Pacific countries in children and adults

\begin{tabular}{|c|c|c|c|c|c|c|c|}
\hline & Country [Ref] & Year of study & Sample size & Mean age (Range) & Serology & $\begin{array}{c}\text { Prevalence (\%), } \\
\text { n:total }\end{array}$ & CI $95 \%$ \\
\hline \multirow{8}{*}{ 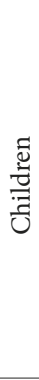 } & India [14] & 2003-2004 & 4,374 & $10.7(3-17)$ & $\mathrm{t}$-TG1 & $(0.32), 1: 310$ & $0.15-0.49$ \\
\hline & Turkey [9] & 2005 & 1,263 & $11.9(6-17)$ & $\mathrm{t}-\mathrm{TG} 1$ & $(0.55), 1: 180$ & $0.14-0.96$ \\
\hline & Turkey [10] & 2006-2008 & 20,190 & $11.6(16-17)$ & t-TG1, EMA ${ }^{1,2}$ & $(0.47), 1: 212$ & $0.38-0.56$ \\
\hline & Iran [16] & $2006-2008$ & 634 & $12.8(7-18)$ & $\mathrm{t}-\mathrm{TG} 1$ & $(0.47), 1: 211$ & $0-1$ \\
\hline & India [13] & 2008-2009 & 3,643 & $10.5(3-17)$ & t-TG1 & (1.41), 1:71 & $1.03-1.79$ \\
\hline & India [15] & 2008-2009 & 400 & $5.6(6 \mathrm{~m}-12 \mathrm{y})$ & $\mathrm{t}-\mathrm{TG}^{1,2}$ & (1), $1: 100$ & $0.02-1.98$ \\
\hline & Iran [17] & 2011-2013 & 1,500 & $9.5(6-12)$ & t-TG1 & $(0.6), 1: 167$ & 0.21-099 \\
\hline & Saudi-Arabia [26] & $2012-2014$ & 1,141 & $11(6-18)$ & t-TG1 & $(0.9), 1: 114$ & $0.35-1.45$ \\
\hline \multirow{12}{*}{$\frac{\stackrel{n}{3}}{\frac{Z}{4}}$} & New-Zealand [24] & 2000 & 1,064 & $50.2(36-74)$ & $\mathrm{EMA}^{1,2}$ & $(1.22), 1: 82$ & $0.56-1.88$ \\
\hline & Australia [25] & 2001 & 3,011 & $40(30-50)$ & EMA1 & $(0.23), 1: 430$ & $0.06-0.40$ \\
\hline & Israel [22] & $2000-2001$ & 1,571 & $40.7(18-76)$ & $\mathrm{t}-\mathrm{TG} 1, \mathrm{EMA}^{1}$ & $(0.63), 1: 157$ & $0.24-1.02$ \\
\hline & Turkey [11] & 2001-2003 & 2,000 & $33(20-59)$ & $\mathrm{t}-\mathrm{TG} 1$ & $(0.70), 1: 141$ & $0.33-1.07$ \\
\hline & Iran [18] & 2003 & 2,000 & $35.5(18-65)$ & AGA1, EMA $^{1}$ & $(0.60), 1: 166$ & $0.26-0.94$ \\
\hline & Israel [23] & 2003 & 850 & $18(18)$ & t-TG1, EMA ${ }^{1}$ & $(0.70), 1: 141$ & $0.14-1.26$ \\
\hline & Iran [19] & 2003-2004 & 2,795 & $33.7(18-66)$ & t-TG1, EMA ${ }^{1}$ & $(0.96), 1: 104$ & $0.60-1.32$ \\
\hline & Iran [21] & 2004 & 1,440 & $45.5(20-38)$ & t-TG1, EMA ${ }^{1}$ & $(0.34), 1: 288$ & $0.04-0.64$ \\
\hline & Iran [20] & $2006-2007$ & 1,600 & $33.2(18-65)$ & $\mathrm{t}-\mathrm{TG} 1$ & $(0.87), 1: 114$ & $0.41-1.33$ \\
\hline & India [13] & 2008-2009 & 6,845 & $34.4(18-64)$ & $\mathrm{t}-\mathrm{TG} 1$ & (0.85), $1: 118$ & $0.63-1.07$ \\
\hline & Turkey [12] & 2011-2013 & 1,554 & $42.1(18-82)$ & $\mathrm{t}-\mathrm{TG}^{1,2} \mathrm{DGP}^{1,2}$ & $(0.39), 1: 259$ & $0.08-0.70$ \\
\hline & Japan [52] & 2014-2016 & 2,008 & $53(25-80)$ & $\mathrm{t}-\mathrm{TG}^{1}, \mathrm{EMA}^{1}$ & $(0.05), 1: 2008$ & $0.01-0.2$ \\
\hline
\end{tabular}

${ }^{1} \mathrm{IgA},{ }^{2} \mathrm{IgG}$, EMA: Anti-endomysial antibodies; AGA: Anti-gliadin antibodies; t-TG: tissue transglutaminase; DGP: deamidated gliadin peptides, CI; Confidence intervals.

\section{Wheat allergy (WA)}

Population studies on WA in the Asia-Pacific region are shown in Table V [68-85].

\section{DISCUSSION}

In recent years, the prevalence of a wide spectrum of GRDs has increased and it can be related to changes in the global dietary habits. In the past, the prevalence of GRDs in AsiaPacific region was underestimated due to lack of awareness of the diseases. Although today awareness of GRDs in the AsiaPacific region has increased, there is still little information available regarding GRDs prevalence. Therefore, we conducted this systematic review to gather the comprehensive information about GRDs in this region. Map 1 shows the available data on at least one of GRDs in the Asia-Pacific region.

Over the past few years, awareness about $\mathrm{CD}$ has increased in Asia-Pacific, indicating by the increasing number of publications on $\mathrm{CD}$ in this region [86]. However, the data on the prevalence of $\mathrm{CD}$ is only available from a few Asian countries and some Middle East countries [87, 88]. According to the data presented in this study, the range of $\mathrm{CD}$ prevalence was reported from $0.23 \%$ to $1.41 \%$ and from $1 \%$ to $11.8 \%$ in healthy and high-risk population, respectively, which is similar to Western countries. In Europe and North America, the prevalence of $\mathrm{CD}$ in the general population is approximately $1 \%$ [89]. The prevalence of CD ranges from 2-3\% in Finland and Sweden to only $0.2 \%$ in Germany [90], and this is similar to the prevalence of $\mathrm{CD}$ in the general population of the Asian-
Pacific region. The prevalence of $\mathrm{CD}$ in diabetes mellitus type 1 (DM1) patients in Western countries has been reported between $1-12 \%$ [91], and is quite similar to that in the AsiaPacific region, which reported a prevalence of $\mathrm{CD}$ between 2.3\%-11.3\% in DM1 patients [33-42]. The CD prevalence in DM1 patients was significantly higher in children compared to adults ( $6 \%$ vs. $2.5 \%$; $\mathrm{P}<0.05)$ in the Asia-Pacific region. The National Institutes of Health (NIH) estimated the prevalence of $\mathrm{CD}$ among the first degree relatives in US to be $4-12 \%$ by biopsy [92]. Moreover, the prevalence of CD in first-degree relatives in Western countries is around $10 \%[93,94]$. The $\mathrm{CD}$ prevalence among first-degree relatives in the Asia-pacific region was found to be lower than in the USA and Western countries (4.4-5.1\%) [47-49]. The prevalence of CD in this region shows a great heterogeneity. This heterogeneity in the Asia-Pacific region is related to highly variable factors such as the level of gluten intake and frequency of HLA-DQ2/ HLA-DQ8 in the population [95]. In Asian-Pacific countries, wheat consumption also varies from as high as more than 100 $\mathrm{kg}$ per year per person in most of the central Asian countries such as Turkey, Iran, Saudi Arabia and Pakistan, to 50-100 kg per year per person in India, China, Australia and New Zealand and under $50 \mathrm{~kg}$ per year per person was estimated in Japan, Korea, Indonesia, Israel and Malaysia [96, 97]. Due to the low consumption of products containing wheat, along with a low frequency of HLA-DQ2/HLA-DQ8 in South East Asian countries, including Korea, Taiwan, Philippines and the smaller islands of the pacific, $\mathrm{CD}$ is still uncommon in these countries [98]. 
Table II. Prevalence of celiac disease among the high-risk population in Asian-Pacific countries in children and adults

\begin{tabular}{|c|c|c|c|c|c|c|c|c|}
\hline & Country $[$ Ref $]$ & Year of study & Risk factor & $\begin{array}{l}\text { Sample } \\
\text { size }\end{array}$ & Mean age (Range) & Serology & $\begin{array}{l}\text { Prevalence (\%), } \\
\text { n:total }\end{array}$ & CI 95\% \\
\hline \multirow{14}{*}{ 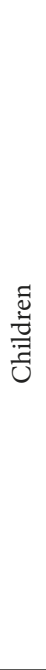 } & Australia [37] & 1990-2009 & DM1 & 4,379 & $6.6(1-8)$ & t-TG1, EMA ${ }^{1}$ & $(4.2) ; 1: 24$ & $3.61-4.79$ \\
\hline & Iran $[43]$ & $1997-2003$ & Chronic diarrhea & 824 & $8.5(3 \mathrm{~m}-14 y)$ & $\mathrm{AGA}^{1}, \mathrm{EMA}^{1}$ & $(8.9) ; 1: 15$ & 6.9610 .84 \\
\hline & Kuwait [34] & $1998-2010$ & DM1 & 47 & $66 \mathrm{M}(7-189 \mathrm{~m})$ & $\mathrm{AGA}^{1,2} \mathrm{EMA}^{1}$ & $(6.4) ; 1: 15$ & $0-13.4$ \\
\hline & Iran [33] & 2003-2004 & DM1 & 87 & $11.7(2-18)$ & $\mathrm{t}-\mathrm{TG}^{1}, \mathrm{EMA}^{1}$ & $(3.4) ; 1: 29$ & $0-7.21$ \\
\hline & Turkey [45] & 2005-2006 & AT & 101 & $12.2(2-18)$ & $\mathrm{t}-\mathrm{TG}^{1}$ & $(4.9) ; 1: 20$ & $0.69-9.11$ \\
\hline & China [44] & $2005-2008$ & Chronic diarrhea & 118 & $(1 \mathrm{~m}-18 \mathrm{y})$ & $\mathrm{t}-\mathrm{TG}^{1}, \mathrm{EMA}^{1}$ & $(11.8) ; 1: 8$ & $5.98-17.62$ \\
\hline & Turkey [29] & 2005 & DS & 100 & $6.01(2-14)$ & $\mathrm{EMA}^{1}$ & $(1) ; 1: 100$ & $0-2.95$ \\
\hline & India [31] & 2007-2009 & DS & 100 & $(2-18)$ & $\mathrm{t}-\mathrm{TG}^{1}, \mathrm{EMA}^{1}$ & $(6) ; 1: 17$ & $1.35-10.65$ \\
\hline & Saudi Arabia [30] & $2007-2011$ & DS & 51 & $4.69(0.57-16.64)$ & $\mathrm{t}-\mathrm{TG}^{1}$ & $(2) ; 1: 51$ & $0-5.84$ \\
\hline & India [47] & $2008-2010$ & First-degree relatives & 91 & $9.5(3-17)$ & $\mathrm{t}-\mathrm{TG}^{1}$ & $(4.4) ; 1: 23$ & $0.19-8.61$ \\
\hline & Saudi Arabia [35] & $2008-2010$ & DM1 & 106 & $8.5(8 m-16 y)$ & $\mathrm{t}-\mathrm{TG}^{1}, \mathrm{EMA}^{1}$ & $(11.3) ; 1: 8$ & $5.27-17.33$ \\
\hline & Oman [36] & 2011-2012 & DM1 & 91 & $10.8(2-17)$ & $\mathrm{t}-\mathrm{TG}^{1}$ & $(5.5) ; 1: 18$ & $0.82-10.18$ \\
\hline & Turkey [38] & 2014-2016 & DM1 & 218 & $12.9(2-18)$ & $\mathrm{t}-\mathrm{TG}^{1}$ & $(5) ; 1: 20$ & $2.11-7.89$ \\
\hline & Iran $[41]$ & $2000-2001$ & DM1 & 250 & $18.7(2-22)$ & $\mathrm{EMA}^{1}$ & $(2.4) ; 1: 41$ & $0.50-4.30$ \\
\hline \multirow{10}{*}{ 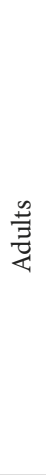 } & Australia [32] & 1997 & DS & 51 & $37(25-62)$ & $\mathrm{EMA}^{1}, \mathrm{AGA}^{1}$ & $(3.9) ; 1: 26$ & $0-9.21$ \\
\hline & Turkey [39] & 2005 & DM1 & 122 & - & $\mathrm{EMA}^{1}$ & $(2.4) ; 1: 41$ & $0-5.12$ \\
\hline & Turkey [46] & $2006-2007$ & AT & 136 & $43.1(17-65)$ & $\mathrm{t}-\mathrm{TG}^{1}$ & $(5.9) ; 1: 17$ & $1.94-9.86$ \\
\hline & Iran $[42]$ & 2006-2007 & DM1 & 100 & $21.8(7-50)$ & $\mathrm{t}-\mathrm{TG}^{1}$ & $(3) ; 1: 34$ & $0-6.34$ \\
\hline & Iran $[50]$ & $2007-2008$ & dyspeptic & 407 & $36.1(\geq 18)$ & $\mathrm{t}-\mathrm{TG}^{1,2}$ & $(2.4) ; 1: 40$ & $0.91-3.89$ \\
\hline & $\operatorname{Iran}[51]$ & 2009-2015 & IBS & 1000 & $29(10-70)$ & $\mathrm{t}-\mathrm{TG}^{1}$ & $(5.7) ; 1: 17$ & $4.26-7.14$ \\
\hline & India $[48]$ & 2009-2014 & First-degree relatives & 434 & 29.8 & $\mathrm{t}-\mathrm{TG}^{1}$ & $(5.1) ; 1: 20$ & $3.03-7.17$ \\
\hline & Turkey [49] & 2012 & first-degree relatives & 484 & - & $\mathrm{t}-\mathrm{TG}^{1}$ & $(4.8) ; 1: 21$ & $2.90-6.70$ \\
\hline & Turkey [40] & $2012-2013$ & DM1 & 425 & $37.6(15-80)$ & $\mathrm{EMA}^{1}$ & $(2.3) ; 1: 42$ & $0.87-3.73$ \\
\hline & Japan [52] & 2014-2016 & Abdominal symptom & 47 & $53(25-80)$ & $\mathrm{t}-\mathrm{TG}^{1}, \mathrm{EMA}^{1}$ & $(2.1) ; 1: 47$ & $0-6.34$ \\
\hline
\end{tabular}

${ }^{1} \mathrm{IgA},{ }^{2} \mathrm{IgG}$, EMA: Anti-endomysial antibodies; AGA: Anti-gliadin antibodies; t-TG: Tissue transglutaminase; DGP: deamidated gliadin peptides; DM1: Diabetes Mellitus type1; DS: Down syndrome; IBS: irritable bowel syndrome, AT: autoimmune thyroiditis; CI; Confidence intervals.

Dermatitis herpetiformis is a relatively rare disease in Asia-Pacific region, and more prevalent in Scandinavian countries and UK. Studies conducted in Scotland and Sweden found an incidence of 11.5 and 19.6 affected individuals per 100,000 , respectively $[99,100]$. The highest prevalence of DH ever reported is in Finland, with 75.3 affected individual per 100,000 [101]. It affects predominantly Caucasians compared to African-Americans or Asians. The only population-based study in Asia-Pacific region reported a prevalence of $\mathrm{DH}$ less than 0.001 per 2.5 million healthy adults in China [54].

Table III. Population studies on dermatitis herpetiformis (DH) and gluten ataxia (GA) in the Asia-Pacific region

\begin{tabular}{|c|c|c|c|c|c|c|c|}
\hline & Country [Ref] & Year & Sample size & Biopsy & Serology & Outcomes & CI 95\% \\
\hline \multirow{6}{*}{ 茎 } & Malaysia[57] & $1975-1990$ & 148 patients with bullous diseases & Yes & $\operatorname{IgA}$ & $\begin{array}{l}\text { No cases of } \mathrm{DH} \\
\text { reported }\end{array}$ & - \\
\hline & China $[54]$ & 1976-1985 & 2.5 million healthy adults & Yes & $\operatorname{IgA}$ & $\begin{array}{l}8 / 2.5 \text { million } \\
(<0.001)\end{array}$ & $0.0006-0.0013$ \\
\hline & China [53] & 1985-1992 & 234 patients with bullous diseases & Yes & IgA, IgG, IgM, C3 & $6 / 234(2.6 \%)$ & $0.56-4.63$ \\
\hline & China [55] & 1993 & 24 patients with IgA deposition & Yes & NR & $1 / 24(4.2 \%)$ & $0-12.22$ \\
\hline & Taiwan [58] & $1995-2008$ & $16 \mathrm{LABD}^{*}$ patients & Yes & IgA, IgG, C3 & $8 / 16(50 \%)$ & $25.5-47.5$ \\
\hline & Singapore $[56]$ & 1998-1999 & 67 patients with SEIBDs ${ }^{\#}$ & Yes & IgG, C3 & $\begin{array}{l}\text { No cases of } \mathrm{DH} \\
\text { reported }\end{array}$ & - \\
\hline \multirow{3}{*}{$\overleftrightarrow{\circlearrowleft}$} & Japan [59] & 2006 & $\begin{array}{l}14 \text { patients with idiopathic } \\
\text { cerebellar ataxia }\end{array}$ & - & $\mathrm{AGA}^{1,2}$ & $1 / 14(7.1 \%)$ & $0-20.5$ \\
\hline & Iran [61] & 2006-2007 & $\begin{array}{l}30 \text { patients with idiopathic } \\
\text { cerebellar ataxia }\end{array}$ & - & $\mathrm{AGA}^{1,2}, \mathrm{AEA}^{1,2}$ & $2 / 30(6.7 \%)$ & $0-15.64$ \\
\hline & Japan $[60]$ & 2014 & 49 patients with cerebellar ataxia & - & $\mathrm{DGP}^{1,2}$ & $8 / 49(8.1 \%)$ & $0.46-15.73$ \\
\hline
\end{tabular}

*LABD: Linear immunoglobulin A bullous dermatosis, ${ }^{*}$ SEIBDs: Subepidermal immunobullous disorders, 1 IgA; ${ }^{2}$ IgG. AEA: Anti-endomysial antibodies; AGA: Anti-gliadin antibodies; t-TG: Tissue transglutaminase. 
Table IV. Population studies on non-celiac gluten sensitivity (NCGS) in the Asia-Pacific region

\begin{tabular}{|c|c|c|c|c|}
\hline Country [Ref] & Year & Population (n) & Methodology & Outcomes \\
\hline $\begin{array}{l}\text { New Zealand } \\
{[62]}\end{array}$ & $1997-2001$ & 916 healthy children & on GFD for 6 weeks & $\begin{array}{l}46 \text { patients out of } 916 \text { had significant reduction } \\
\text { symptoms with GFD; } 46 / 916(5.0 \%)\end{array}$ \\
\hline Australia [65] & $2007-2008$ & $\begin{array}{l}34 \text { adult Patients with IBS } \\
\text { without CD (29-59 Y) }\end{array}$ & $\begin{array}{l}\text { DBPC challenge } \\
6 \text { weeks on GFD }\end{array}$ & $\begin{array}{l}\text { Significant reduction in symptoms in GFD group, } 13 \\
\text { patients out of } 34 \text { patients in this group had reduce } \\
\text { symptoms after GFD; } 13 / 34(38.2 \%)\end{array}$ \\
\hline Iran [66] & 2011-2013 & $\begin{array}{l}148 \text { adult Patients with IBS } \\
\text { (Based on Rome III criteria) }\end{array}$ & $\begin{array}{l}\text { DBPC challenge } \\
6 \text { weeks on GFD }\end{array}$ & $\begin{array}{l}\text { Worsening of intestinal symptoms with gluten } \\
\text { compared to placebo } \\
31 \text { patients out of } 72 \text { IBS patients who commenced on } \\
\text { a GFD for six weeks suffered from gluten sensitivity; } \\
31 / 72(43.0 \%)\end{array}$ \\
\hline India [67] & 2013-2015 & $\begin{array}{l}65 \text { patients with IBS(Based on } \\
\text { Rome III criteria) without CD } \\
\text { and WA } \\
\text { Older than } 16 \text { years }\end{array}$ & $\begin{array}{l}\text { DBPC challenge } \\
4 \text { weeks on GFD }\end{array}$ & $\begin{array}{l}\text { Significant reduction in visual analog scales } \\
\text { (VAS) of symptomatology } \\
\text { The patients in the gluten intervention group scored } \\
\text { significantly higher in terms of abdominal pain, } \\
\text { bloating, and tiredness }(\mathrm{P}<0.05) \text {, and their symptoms } \\
\text { worsened within } 1 \text { week of the challenge. }\end{array}$ \\
\hline
\end{tabular}

DBPC: double-blind placebo controlled, GFD: gluten free diet

Even in other countries in this region, such as Singapore and Malaysia, despite the studies on at risk populations (patients with bullous diseases), no cases have been reported $[56,57]$. The characteristics of 22 Chinese patients with DH from 2006 to 2010 were assessed and compared to Caucasian populations. The clinical, histological and immunepathological characteristics of these patients were similar to
Caucasian populations, but the positive rates of anti-EMA and anti-tTG antibodies were lower compared with those seen in Western countries [102]. To date, large epidemiological studies on the prevalence of GA in Asia-Pacific region have not been published. According to the data presented in this review, the only GA prevalence was reported in patients with idiopathic cerebellar ataxia, not in the general population,

Table V. Population studies on wheat allergy (WA) in the Asia-Pacific region

\begin{tabular}{|c|c|c|c|c|c|c|}
\hline Country [Ref] & Year & Population (n) & Age & Methodology & Wheat (\%) & CI 95\% \\
\hline Australia [68] & 1997-1998 & 620 healthy infant & 0-24 months & $\begin{array}{l}\text { SPT performed at } 6 \text {, } \\
12 \text {, and } 24 \text { months }\end{array}$ & $1 / 620(0.16 \%)$ & $0-0.47$ \\
\hline Korea [76] & $2000-2006$ & $\begin{array}{l}978,146 \text { healthy population } \\
138 \text { patients with anaphylaxis }\end{array}$ & $0-70$ years & SPT, IgE tests & $\begin{array}{l}6 / 978,146(<0.001 \%) \\
6 / 138(4.3 \%)\end{array}$ & $\begin{array}{l}0-0.0016 \\
0.91-7.68\end{array}$ \\
\hline Iran [69] & 2003 & $\begin{array}{l}190 \text { children with allergy } \\
\text { symptoms }\end{array}$ & $\leq 12$ years & $\begin{array}{l}\text { SPT, Specific serum } \\
\text { IgE tests }\end{array}$ & $7 / 190(3.7 \%)$ & $1.01-6.38$ \\
\hline Iran [69] & 2003 & $\begin{array}{l}24 \text { children with allergy } \\
\text { symptoms }\end{array}$ & $\leq 1$ years & $\begin{array}{l}\text { SPT, Specific serum } \\
\text { IgE tests }\end{array}$ & $1 / 24(4.1 \%)$ & $0-12.03$ \\
\hline Iran [69] & 2003 & $\begin{array}{l}63 \text { children with allergy } \\
\text { symptoms }\end{array}$ & 1-3 years & $\begin{array}{l}\text { SPT, Specific serum } \\
\text { IgE tests }\end{array}$ & $2 / 63(3.1 \%)$ & $0-7.38$ \\
\hline Iran [69] & 2003 & $\begin{array}{l}39 \text { children with allergy } \\
\text { symptoms }\end{array}$ & 3-6 years & $\begin{array}{l}\text { SPT, Specific serum } \\
\text { IgE tests }\end{array}$ & $1 / 39(2.5 \%)$ & $0-7.40$ \\
\hline Iran [69] & 2003 & $\begin{array}{l}64 \text { children with allergy } \\
\text { symptoms }\end{array}$ & $6-12$ years & $\begin{array}{l}\text { SPT, Specific serum } \\
\text { IgE tests }\end{array}$ & $3 / 64(4.6 \%)$ & $0-9.73$ \\
\hline Singapore [74] & $2003-2006$ & $\begin{array}{l}413 \text { children with allergy } \\
\text { symptoms }\end{array}$ & $\leq 12$ years & SPT & $13 / 413(3.1 \%)$ & $1.42-4.77$ \\
\hline Iran [70] & 2005-2009 & $\begin{array}{l}69 \text { children with history of } \\
\text { anaphylaxis }\end{array}$ & $\leq 14$ years & $\begin{array}{l}\text { SPT, Specific serum } \\
\text { IgE tests }\end{array}$ & $18 / 69(26.1 \%)$ & $22.6-29.5$ \\
\hline Japan [78] & 2009-2010 & 935 healthy adult & 24-39 years & SPT, $\omega-5$ gliadin IgE & $2 / 935(0.21 \%)$ & $0-0.50$ \\
\hline Japan [79] & 2010 & 101,322 healthy children & $0-6$ years & SPT, $\omega-5$ gliadin IgE & $375 / 101,322(0.37 \%)$ & $0.33-0.40$ \\
\hline Iran [71] & $2012-2014$ & $\begin{array}{l}371 \text { patients with allergy } \\
\text { symptoms }\end{array}$ & $3 \mathrm{~m}-18$ years & $\begin{array}{l}\text { SPT, Specific serum } \\
\text { IgE tests }\end{array}$ & $8 / 371(2.1 \%)$ & $0.64-3.55$ \\
\hline Malaysia [72] & 2015 & $\begin{array}{l}\text { Totally: } 192 \text { allergic children } \\
<2 \text { years: } 35 \text { allergic children } \\
\text { 2-10 years: } 157 \text { allergic } \\
\text { children }\end{array}$ & $0-10$ years & $\begin{array}{l}\text { Specific serum IgE } \\
\text { tests }\end{array}$ & $\begin{array}{l}20 / 192(10.4 \%) \quad 6 / 35 \\
(17.1 \%) \quad 14 / 157 \\
(8.9 \%)\end{array}$ & $\begin{array}{l}6.08-14.71 \\
4.62-29.5 \\
4.44-13.35\end{array}$ \\
\hline Pakistan [73] & 2016 & 689 adult allergic patients & $15-73$ years & $\begin{array}{l}\text { self-report, SPT and } \\
\text { OFC }\end{array}$ & $\begin{array}{l}\text { By SPT: } 154 / 689 \\
(22.3 \%) \text { By OFC: } \\
11 / 101(10.9 \%)\end{array}$ & $\begin{array}{l}19.19-25.4 \\
8.57-13.22\end{array}$ \\
\hline
\end{tabular}

SPT: skin prick test, OFC; oral food challenge test; CI; Confidence intervals. 


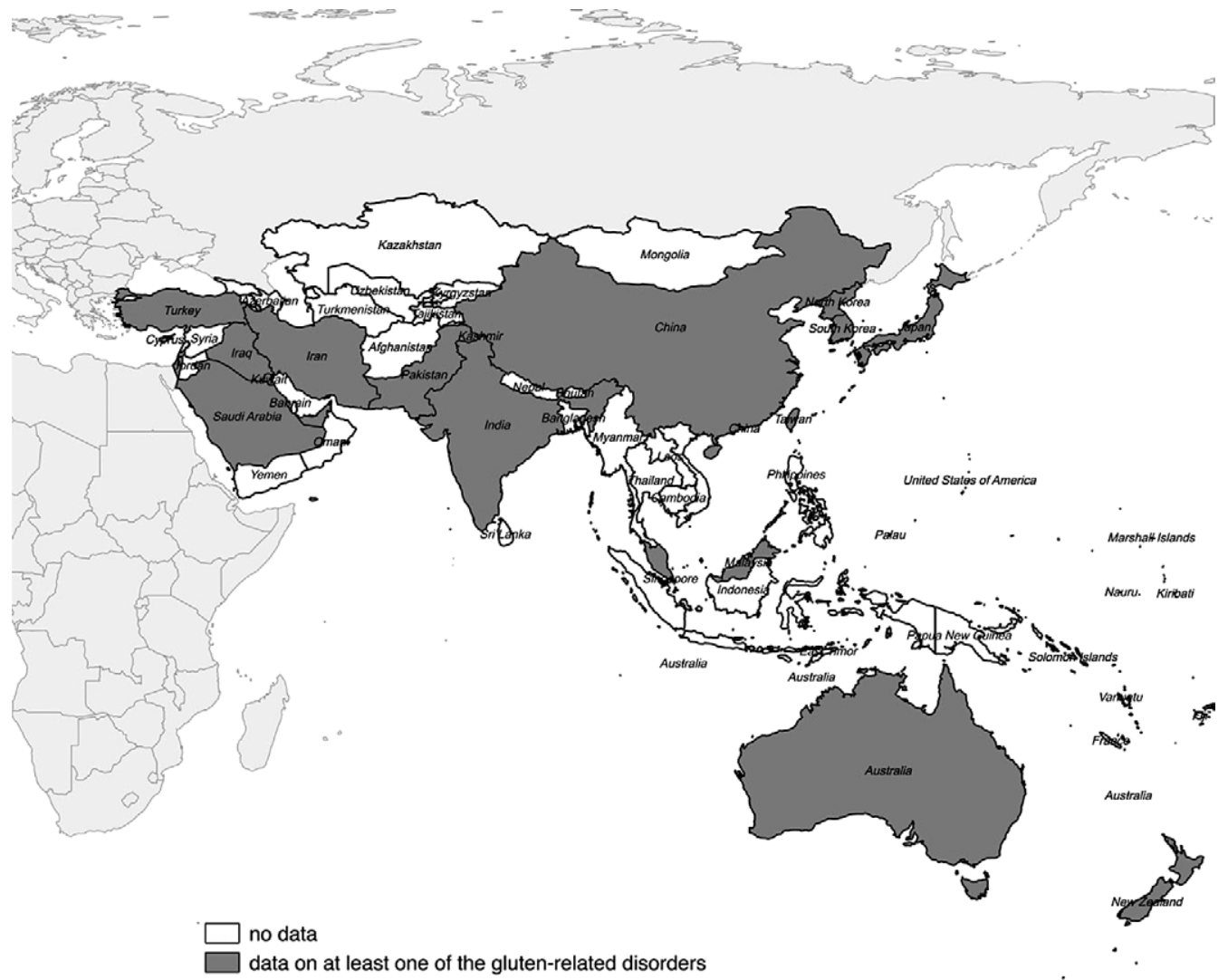

Map 1. The available data on at least one of the GRDs in Asia-Pacific region

and this was very low [59-61]. The low prevalence of GA in the Asian-Pacific region could be explained by incomplete experimental evidence and small sample size studies in this region, differences in genetics and nutritional habits and also by the effect of serologic tests in clinical versus research setting. To determine the exact prevalence of GA in Asia-Pacific region, further studies in other countries are necessary. Nevertheless, GA should be recognized as an important disease, causing cerebellar ataxia in Asia, despite having a lower incidence than Western countries.

For two main reasons, there is little information about the prevalence of NCGS in the Asia-Pacific region; a) there is no specific biomarker for NCGS and the diagnosis is very difficult, and b) many people make a self-diagnosis and start a GFD without medical advice or consultation [103]. Doubleblind placebo controlled (DBPC) approach using $8 \mathrm{gr}$ of gluten is presented as gold standard for the exact scientific identification of real cases based on "Salerno criteria" [104]. Patients frequently refuse to re-introduce gluten into their diet due to the re-occurrence of symptoms. However, according to the most recent data, NCGS is not an uncommon disorder. Prevalence rates of NCGS differed widely from $0.5 \%$ to $14 \%$ in different countries $[105,106]$. There is not much information about the prevalence of NCGS in the Asia-Pacific region. We found only 4 NCGS studies in this area [62, 65-67]. In all studies, the DBPC challenge has been used as a gold standard for the detection of NCGS cases and all cases had significant reduction of symptoms with GFD. In a recent meta-analysis by Lionetti et al., the prevalence of NCGS after gluten re-challenge was low and the percentage of relapse after a gluten and placebo challenge was similar [107].
The prevalence of WA has dramatically increased in recent years in the Asia-Pacific region. Unfortunately, reports on WTA prevalence in Asia-Pacific are limited and epidemiologic studies in the general population or among children are very few. Wheat allergy, although uncommon in most Asian-Pacific countries, is the most common cause of anaphylaxis in this region [70, 76]. Wheat allergy among the adult allergic patients in Pakistan and India (22\%) was the predominant type of allergy [73, 108]. A large recent review [109] found that the overall prevalence of food allergy in Asia-Pacific is fairly comparable to that in the West, although this kind of allergies differs in order to relevance in the consumption of type of food. In Japan, similar to Germany and Finland, WA has been reported as the third most common allergen after milk and egg allergy [110]. According to previous studies in Western countries, the prevalence of WA was reported to be about $1 \%(0.4 \%-4 \%)$ in the general population [111-113]. While a study from the USA reported a prevalence of WA in patients with food allergies between $11 \%$ and $20 \%$ in children, and 25\% in adults [114]. The studies from Asia-Pacific region indicate that the prevalence of WA widely ranges from $0.16 \%$ to $26.1 \%$. This heterogeneity of WA prevalence depends on whether the studies have been conducted on the healthy general population or subjects with allergy symptoms. Studies on healthy population and subjects with allergy symptoms showed that the prevalence of WA ranges from 0.16 to $0.37 \%$ and from $10.4 \%$ to $26.1 \%$, respectively.

\section{CONCLUSIONS}

The prevalence of GRDs in Asia-Pacific region shows a great heterogeneity. Despite the improvement in diagnostic tests 
for CD, it is difficult to distinguish GRDs based on a clinical presentation. Diagnostic tests for WA are unsatisfactory, and no specific biomarkers or objective diagnostic criteria have been identified for the diagnosis of NCGS. Therefore, further studies are required to determine the exact prevalence of GRDs in Asia-Pacific region.

Conflicts of interest: The authors declare no conflicts of interest.

Authors contribution: M.R.N. and K.R. designed the study. M.A.P., H.A.A., M.R.Z., M.R.T., L.B. contributed to the concept of the review. S.A. performed the database and papers selection for the review and wrote the draft of review. All authors revised the manuscript and approved the final version.

Acknowledgments: This study was performed in the Gastroenterology and Liver Diseases Research Center of Shahid Beheshti University of Medical Sciences and supported by grant number 13637-5.

\section{REFERENCES}

1. Tovoli F, Masi C, Guidetti E, Negrini G, Paterini P, Bolondi L. Clinical and diagnostic aspects of gluten related disorders. World J Clin Cases 2015;3:275-284. doi:10.12998/wjcc.v3.i3.275

2. Volta U, Caio G, Tovoli F, De Giorgio R. Non-celiac gluten sensitivity: questions still to be answered despite increasing awareness. Cell Mol Immunol 2013;10:383-392. doi:10.1038/cmi.2013.28

3. Sapone A, Bai JC, Ciacci C, et al. Spectrum of gluten-related disorders: consensus on new nomenclature and classification. BMC Med 2012;10:13. doi:10.1186/1741-7015-10-13

4. Moher D, Liberati A, Tetzlaff J, Altman DG; PRISMA Group. Preferred reporting items for systematic reviews and meta-analyses: the PRISMA statement. Ann Intern Med 2009;151:264-269. doi:10.7326/0003-4819. 151-4-200908180-00135

5. Revised criteria for diagnosis of coeliac disease. Report of Working Group of European Society of Paediatric Gastroenterology and Nutrition. Arch Dis Child 1990;65:909-911.

6. N Marsh M, W Johnson M, Rostami K. Mucosal histopathology in celiac disease: a rebuttal of Oberhuber's sub-division of Marsh III. Gastroenterol Hepatol Bed Bench 2015;8:99-109.

7. Husby S, Koletzko S, Korponay-Szabo IR, et al. European Society for Pediatric Gastroenterology, Hepatology, and Nutrition guidelines for the diagnosis of coeliac disease. J Pediatr Gastroenterol Nutr 2012;54:136160. doi:10.1097/MPG.0b013e31821a23do

8. Catassi C, Elli L, Bonaz B, et al. Diagnosis of Non-Celiac Gluten Sensitivity (NCGS): The Salerno Experts' Criteria. Nutrients 2015;7:4966-9477. doi:10.3390/nu7064966

9. Ertekin V, Selimoglu MA, Kardas F, Aktas E. Prevalence of celiac disease in Turkish children. J Clin Gastroenterol 2005;39:689-691. doi:10.1097/01.mcg.0000174026.26838.56

10. Dalgic B, Sari S, Basturk B, et al. Prevalence of celiac disease in healthy Turkish school children. Am J Gastroenterol 2011;106:1512-1517. doi:10.1038/ajg.2011.183

11. Tatar G, Elsurer R, Simsek H, et al. Screening of tissue transglutaminase antibody in healthy blood donors for celiac disease screening in the Turkish population. Dig Dis Sci 2004;49:1479-1484. doi:10.1023/ B:DDAS.0000042250.59327.91
12. Sezgin O, Saritaş B, Aydin I, Şaşmaz T, Serinoz ES. Celiac Disease Prevalence in Turkey: A Population Based Cross-Sectional Study. Acta Med Mediterr 2016;32:719-727. doi:10.19193/03936384_2016_3_80

13. Makharia GK, Verma AK, Amarchand R, et al. Prevalence of celiac disease in the northern part of India: a community based study. J Gastroenterol Hepatol 2011;26:894-900. doi:10.1111/j.14401746.2010.06606.x

14. Sood A, Midha V, Sood N, Avasthi G, Sehgal A. Prevalence of celiac disease among school children in Punjab, North India. J Gastroenterol Hepatol 2006;21:1622-1625. doi:10.1111/j.1440-1746.2006.04281.x

15. Bhattacharya M, Dubey AP, Mathur NB. Prevalence of celiac disease in north Indian children. Indian Pediatr 2009;46:415-417.

16. Farahmand F, Mir-Nasseri MM, Shahraki T, et al. Prevalence of occult celiac disease in healthy Iranian school age children. Arch Iran Med 2012;15:342-345.

17. Dehghani SM, Haghighat M, Mobayen A, Rezaianzadeh A, Geramizadeh B. Prevalence of celiac disease in healthy Iranian school children. Ann Saudi Med 2013;33:159-161. doi:10.5144/0256-4947.2013.159

18. Shahbazkhani B, Malekzadeh R, Sotoudeh M, et al. High prevalence of coeliac disease in apparently healthy Iranian blood donors. Eur J Gastroenterol Hepatol 2003;15:475-478. doi:10.1097/01. meg.0000059118.41030.96

19. Akbari MR, Mohammadkhani A, Fakheri H, et al. Screening of the adult population in Iran for coeliac disease: comparison of the tissue-transglutaminase antibody and anti-endomysial antibody tests. Eur J Gastroenterol Hepatol 2006;18:1181-1186. doi:10.10 97/01. meg.0000224477.51428.32

20. Bahari A, Karimi M, Sanei-Moghaddam I, Firouzi F, Hashemi M. Prevalence of celiac disease among blood donors in Sistan and Balouchestan Province, Southeastern Iran. Arch Iran Med 2010;13:301305.

21. Saberi-Firouzi M, Omrani GR, Nejabat M, Mehrabani D, Khademolhosseini F. Prevalence of celiac disease in Shiraz, southern Iran. Saudi J Gastroenterol 2008;14:135-138. doi:10.4103/13193767.41732

22. Shamir R, Lerner A, Shinar E, et al. The use of a single serological marker underestimates the prevalence of celiac disease in Israel: a study of blood donors. Am J Gastroenterol 2002;97:2589-2594. doi:10.1111/j.15720241.2002.06028.x

23. Israeli E, Hershcovici T, Grotto I, Rouach Z, Branski D, Goldin E. Prevalence of celiac disease in an adult Jewish population in Israel. Isr Med Assoc J 2010;12:266-269.

24. Cook HB, Burt MJ, Collett JA, Whitehead MR, Frampton CM, Chapman BA. Adult coeliac disease: prevalence and clinical significance. J Gastroenterol Hepatol 2000;15:1032-1036. doi:10.1046/j.14401746.2000.02290.x

25. Hovell CJ, Collett JA, Vautier G, et al. High prevalence of coeliac disease in a population-based study from Western Australia: a case for screening? Med J Aust 2001;175:247-250.

26. Al Hatlani MM. Prevalence of celiac disease among symptomfree children from the Eastern Province of Saudi Arabia. Saudi J Gastroenterol 2015;21:367-371. doi:10.4103/1319-3767.170952

27. Makharia GK. Celiac disease screening in southern and East Asia. Dig Dis 2015;33:167-174. doi:10.1159/000369537

28. Barada K, Bitar A, Mokadem MA, Hashash JG, Green P. Celiac disease in Middle Eastern and North African countries: a new burden? World J Gastroenterol 2010;16:1449-1457. doi:10.3748/wjg.v16.i12.1449 
29. Alanay Y, Boduroglu K, Tuncbilek E. Celiac disease screening in 100 Turkish children with Down syndrome. Turk J Pediatr 2005;47:138-140.

30. Saadah OI, Al-Aama JY, Alaifan MA, Bin Talib YY, Al-Mughales JA. Prevalence of celiac disease in children with Down syndrome screened by anti-tissue transglutaminase antibodies. Saudi Med J 2012;33:208210.

31. Bhat AS, Chaturvedi MK, Saini S, et al. Prevalence of celiac disease in Indian children with Down syndrome and its clinical and laboratory predictors. Indian J Pediatr 2013;80:114-117. doi:10.1007/s12098-0120838-1

32. Gale L, Wimalaratna H, Brotodiharjo A, Duggan JM. Down's syndrome is strongly associated with coeliac disease. Gut 1997;40:492-496. doi:10.1136/gut.40.4.492

33. Moayeri H, Bahremand SH. Prevalence of celiac disease of children and adolecents with type I diabetes mellitus. Med J Islam Repub Iran 2004;18:39-43.

34. Al-Qabandi W, Buhamrah E, Al-Abdulrazzaq D, Hamadi K, Al Refaee F. Celiac disease in children: is it a problem in Kuwait? Clin Exp Gastroenterol 2015;8:43-48. doi:10.2147/CEG.S73067

35. Al-Hussaini A, Sulaiman N, Al-Zahrani M, Alenizi A, El Haj I. High prevalence of celiac disease among Saudi children with type 1 diabetes: a prospective cross-sectional study. BMC Gastroenterol 2012;12:180. doi:10.1186/1471-230x-12-180

36. Al-Sinani S, Sharef SW, Al-Yaarubi S, et al. Prevalence of celiac disease in omani children with type 1 diabetes mellitus: a cross sectional study. Oman Med J 2013;28:260-263. doi:10.5001/omj.2013.73

37. Pham-Short A, Donaghue KC, Ambler G, Chan AK, Craig ME. Coeliac disease in Type 1 diabetes from 1990 to 2009: higher incidence in young children after longer diabetes duration. Diabet Med 2012;29:e286-e289. doi:10.1111/j.1464-5491.2012.03720.x

38. Yildirmaz S, Altay D, Esen I, Dogan Y. Prevalence of Celiac Disease in Children With Type 1 Diabetes Mellitus in Southeast Region of Turkey. Int J Clin Pediatr 2016;5:32-35. doi:10.14740/ijcp239w

39. Aygun C, Uraz S, Damci T, et al. Celiac disease in an adult Turkish population with type 1 diabetes mellitus. Dig Dis Sci 2005;50:1462-1466. doi:10.1007/s10620-005-2862-8

40. Dogan B, Oner C, Bayramicli OU, Yorulmaz E, Feyizoglu G, Oguz A. Prevalence of celiac disease in adult type 1 patients with diabetes. Pak J Med Sci 2015;31:865-868. doi:10.12669/pjms.314.7206

41. Shahbazkhani B, Faezi T, Akbari MR, et al. Coeliac disease in Iranian type I diabetic patients. Dig Liver Dis 2004;36:191-194. doi:10.1016/j. dld.2003.10.015

42. Sharifi N, Khoshbaten M, Aliasgarzade A, Bahrami A. Celiac disease in patients with type-1 diabetes mellitus screened by tissue transglutaminase antibodies in northwest of Iran. Int J Diabetes Dev Ctries 2008;28:95-99. doi:10.4103/0973-3930.44081

43. Imanzadeh F, Sayyari AA, Yaghoobi M, Akbari MR, Shafagh H, Farsar AR. Celiac disease in children with diarrhea is more frequent than previously suspected. J Pediatr Gastroenterol Nutr 2005;40:309-311. doi:10.1097/01.MPG.0000154012.10420.08

44. Wang XQ, Liu W, Xu CD, et al. Celiac disease in children with diarrhea in 4 cities in China. J Pediatr Gastroenterol Nutr 2011;53:368-370.

45. Sari S, Yesilkaya E, Egritas O, Bideci A, Dalgic B. Prevalence of celiac disease in Turkish children with autoimmune thyroiditis. Dig Dis Sci 2009;54:830-832. doi:10.1007/s10620-008-0437-1

46. Guliter S, Yakaryilmaz F, Ozkurt Z, et al. Prevalence of coeliac disease in patients with autoimmune thyroiditis in a Turkish population. World J Gastroenterol 2007;13:1599-1601.
47. Srivastava A, Yachha SK, Mathias A, Parveen F, Poddar U, Agrawal S. Prevalence, human leukocyte antigen typing and strategy for screening among Asian first-degree relatives of children with celiac disease. J Gastroenterol Hepatol 2010;25:319-324. doi:10.1111/j.14401746.2009.06044.X

48. Mishra A, Prakash S, Kaur G, et al. Prevalence of celiac disease among first-degree relatives of Indian celiac disease patients. Dig Liver Dis 2016;48:255-259. doi:10.1016/j.dld.2015.11.007

49. Dogan Y, Yildirmaz S, Ozercan IH. Prevalence of celiac disease among first-degree relatives of patients with celiac disease. J Pediatr Gastroenterol Nutr 2012;55:205-208. doi:10.1097/MPG.0b013e318249378c

50. Rostami Nejad M, Mahbobipour H, Fazeli Z, et al. Celiac disease in dyspeptic patients. Koomesh 2011;12:209-214.

51. Mahmoodi A, Jafarihaydarlo A, Yasemi M, Hemati K, Peyman H. Celiac disease prevalence in the patients with irritable bowel syndrome in the ilam province; a cross sectional study from Western iran. J Clin Diagn Res 2014;8:GC01-GC03. doi:10.7860/JCDR/2014/10175.5286

52. Fukunaga M, Ishimura N, Fukuyama C, et al. Celiac disease in non-clinical populations of Japan. J Gastroenterol 2018;53:208-214. doi:10.1007/s00535-017-1339-9

53. Su RCW, Chong LY. Chronic bullous dermatosis in Hong Kong. Hong Kong Med J 1996;2:366-372.

54. Ratnam KV. IgA dermatosis in an adult Chinese population. A 10-year study of linear IgA and dermatitis herpetiformis in Singapore. Int J Dermatol 1988;27:21-24. doi:10.1111/j.1365-4362.1988.tb02328.x

55. Weng MW, Qiu BS, Kang KF. An analysis of 24 patients with IgA deposition at the BMZ. J Dermatol 1993;20:276-278. doi:10.1111/j.1346-8138.1993. tb01391.x

56. Wong SN, Chua SH. Spectrum of subepidermal immunobullous disorders seen at the National Skin Centre, Singapore: a 2-year review. Br J Dermatol 2002;147:476-480. doi:10.1046/j.13652133.2002.04919.x

57. Adam BA. Bullous diseases in Malaysia: epidemiology and natural history. Int J Dermatol 1992;31:42-45. doi:10.1111/j.1365-4362.1992. tb03519.x

58. Tsai IC, Chu CY, Chen HJ, Wang LF, Chiu HJ. Linear IgA bullous dermatosis: a clinical study of 16 cases at National Taiwan University Hospital. Dermatol Sin 2010;28:21-26. doi:10.1016/S10278117(10)60003-1

59. Ihara M, Makino F, Sawada H, et al. Gluten sensitivity in Japanese patients with adult-onset cerebellar ataxia. Intern Med 2006;45:135-140. doi:10.2169/internalmedicine.45.1351

60. Nanri K, Mitoma H, Ihara M, et al. Gluten ataxia in Japan. Cerebellum 2014;13:623-627. doi:10.1007/s12311-014-0582-3

61. Hamidian Y, Togha M, Nafisi S, et al. Antigliadin antibody in sporadic adult ataxia. Iran J Neurol 2012;11:16-20.

62. Tanpowpong P, Ingham TR, Lampshire PK, et al. Coeliac disease and gluten avoidance in New Zealand children. Arch Dis Child 2012;97:1216. doi:10.1136/archdischild-2011-300248

63. Makharia A, Catassi C, Makharia GK. The Overlap between Irritable Bowel Syndrome and Non-Celiac Gluten Sensitivity: A Clinical Dilemma. Nutrients 2015;7:10417-10426. doi:10.3390/nu7125541

64. Lu W, Gwee KA, Siah KT, Kang JY, Lee R, Ngan CC. Prevalence of Anti-deamidated Gliadin Peptide Antibodies in Asian Patients With Irritable Bowel Syndrome. J Neurogastroenterol Motil 2014;20:236-241. doi:10.5056/jnm.2014.20.2.236

65. Biesiekierski JR, Newnham ED, Irving PM, et al. Gluten causes gastrointestinal symptoms in subjects without celiac disease: a 
double-blind randomized placebo-controlled trial. Am J Gastroenterol 2011;106:508-514. doi:10.1038/ajg.2010.487

66. Shahbazkhani B, Sadeghi A, Malekzadeh R, et al. Non-Celiac Gluten Sensitivity Has Narrowed the Spectrum of Irritable Bowel Syndrome: A Double-Blind Randomized Placebo-Controlled Trial. Nutrients 2015;7:4542-4554. doi:10.3390/nu7064542

67. Zanwar VG, Pawar SV, Gambhire PA, et al. Symptomatic improvement with gluten restriction in irritable bowel syndrome: a prospective, randomized, double blinded placebo controlled trial. Intest Res 2016;14:343-350. doi:10.5217/ir.2016.14.4.343

68. Hill DJ, Hosking CS, Zhie CY, et al. The frequency of food allergy in Australia and Asia. Environ Toxicol Pharmacol 1997;4:101-110. doi:10.1016/S1382-6689(97)10049-7

69. Pourpak Z, Farhoudi A, Arshi S, et al. Common Food Allergens in Iranian Children. Iran J Med Sci 2003;28:17-22.

70. Barzegar S, Rosita A, Pourpak Z, et al. Common causes of anaphylaxis in children: the first report of anaphylaxis registry in iran. World Allergy Organ J 2010;3:9-13. doi:10.1097/WOX.0b013e3181c82128

71. Ahanchian H, Jafari S, Behmanesh F, et al. Epidemiological survey of pediatric food allergy in Mashhad in Northeast Iran. Electron Physician 2016;8:1727-1732. doi:10.19082/1727

72. Yadav A, Naidu R. Clinical manifestation and sensitization of allergic children from Malaysia. Asia Pac Allergy 2015;5:78-83. doi:10.5415/ apallergy.2015.5.2.78

73. Inam M, Shafique RH, Roohi N, Irfan M, Abbas S, Ismail M. Prevalence of sensitization to food allergens and challenge proven food allergy in patients visiting allergy centers in Rawalpindi and Islamabad, Pakistan. Springerplus 2016;5:1330. doi:10.1186/s40064-016-2980-0

74. Chiang WC, Kidon MI, Liew WK, Goh A, Tang JP, Chay OM. The changing face of food hypersensitivity in an Asian community. Clin Exp Allergy 2007;37:1055-1061. doi:10.1111/j.13652222.2007.02752.x

75. Ebisawa M, Ito K, Fujisawa T; Committee for Japanese Pediatric Guideline for Food Allergy, The Japanese Society of Pediatric Allergy and Clinical Immunology, The Japanese Society of Allergology. Japanese guidelines for food allergy 2017. Allergol Int 2017;66:248-264. doi:10.1016/j.alit.2017.02.001

76. Yang MS, Lee SH, Kim TW, et al. Epidemiologic and clinical features of anaphylaxis in Korea. Ann Allergy Asthma Immunol 2008;100:31-36. doi:10.1016/s1081-1206(10)60401-2

77. Imamura T, Kanagawa Y, Ebisawa M. A survey of patients with selfreported severe food allergies in Japan. Pediatr Allergy Immunol 2008;19:270-274. doi:10.1111/j.1399-3038.2007.00621.x

78. Morita E, Chinuki Y, Takahashi H, Nabika T, Yamasaki M, Shiwaku K. Prevalence of wheat allergy in Japanese adults. Allergol Int 2012;61:101105. doi:10.2332/allergolint.11-OA-0345

79. Noda R. Prevalence of food allergy in nursery school (nationwide survey). Jpn J Food Allergy 2010;10:5-9.

80. Wu TC, Tsai TC, Huang CF, et al. Prevalence of food allergy in Taiwan: a questionnaire-based survey. Intern Med J 2012;42:1310-1315. doi:10.1111/j.1445-5994.2012.02820.x

81. Leung TF, Yung E, Wong YS, Lam CW, Wong GW. Parent-reported adverse food reactions in Hong Kong Chinese pre-schoolers: epidemiology, clinical spectrum and risk factors. Pediatr Allergy Immunol 2009;20:339-346. doi:10.1111/j.1399-3038.2008.00801.x

82. Chen J, Liao Y, Zhang HZ, Zhao H, Chen J, Li HQ. Prevalence of food allergy in children under 2 years of age in three cities in China. Zhonghua Er Ke Za Zhi 2012;50:5-9.
83. Lao-araya M, Trakultivakorn M. Prevalence of food allergy among preschool children in northern Thailand. Pediatr Int 2012;54:238-243. doi:10.1111/j.1442-200X.2011.03544.x

84. Kaya A, Erkocoglu M, Civelek E, Cakir B, Kocabas CN. Prevalence of confirmed IgE-mediated food allergy among adolescents in Turkey. Pediatr Allergy Immunol 2013;24:456-462. doi:10.1111/pai.12097

85. Aaronov D, Tasher D, Levine A, Somekh E, Serour F, Dalal I Natural history of food allergy in infants and children in Israel. Ann Allergy Asthma Immunol 2008;101:637-640. doi:10.1016/s10811206(10)60228-1

86. Singh P, Arora S, Singh A, Strand TA, Makharia GK. Prevalence of celiac disease in Asia: A systematic review and meta-analysis. J Gastroenterol Hepatol 2016;31:1095-1101. doi:10.1111/jgh.13270

87. Gursoy S, Guven K, Simsek T, et al. The prevalence of unrecognized adult celiac disease in Central Anatolia. J Clin Gastroenterol 2005;39:508-511.

88. Rostami Nejad M, Rostami K, Emami M, Zali M, Malekzadeh R. Epidemiology of celiac disease in iran: a review. Middle East J Dig Dis 2011;3:5-12.

89. Fasano A, Catassi C. Clinical practice. Celiac disease. N Engl J Med 2012;367:2419-2426. doi:10.1056/NEJMcp1113994

90. Mustalahti K, Catassi C, Reunanen A, et al. The prevalence of celiac disease in Europe: results of a centralized, international mass screening project. Ann Med 2010;42:587-595. doi:10.3109/07853890.2010.505931

91. Rostom A, Murray JA, Kagnoff MF. American Gastroenterological Association (AGA) Institute technical review on the diagnosis and management of celiac disease. Gastroenterology 2006;131:1981-2002. doi:10.1053/j.gastro.2006.10.004

92. Book L, Zone JJ, Neuhausen SL. Prevalence of celiac disease among relatives of sib pairs with celiac disease in U.S. families. Am J Gastroenterol 2003;98:377-381. doi:10.1111/j.1572-0241.2003.07238.x

93. Greco L, Romino R, Coto I, et al. The first large population based twin study of coeliac disease. Gut 2002;50:624-628. doi:10.1136/gut.50.5.624

94. Ludvigsson JF, Leffler DA, Bai JC, et al. The Oslo definitions for coeliac disease and related terms. Gut 2013;62:43-52. doi:10.1136/ gutjnl-2011-301346

95. Rostami Nejad M, Aldulaimi D, Ishaq S, et al. Geographic trends and risk of gastrointestinal cancer among patients with celiac disease in Europe and Asian-Pacific region. Gastroenterol Hepatol Bed Bench 2013;6:170-177.

96. Sharkey LM, Corbett G, Currie E, Lee J, Sweeney N, Woodward JM. Optimising delivery of care in coeliac disease - comparison of the benefits of repeat biopsy and serological follow-up. Aliment Pharmacol Ther 2013;38:1278-1291. doi:10.1111/apt.12510

97. Aquino P, Carrión F, Calvo R. Selected Wheat Statistics. 2001 CIMMYT World Wheat Overview and Outlook. Cited 1 June 2009. Available from URL: http://www.cimmyt.org/research/Economics/map/facts_trends/ wheat00-01/pdf/wheato\&o00-01.pdf. 2009.

98. Peña AS, Rodrigo L. Epidemiology of Celiac Disease and Non-celiac Gluten-Related Disorders. In Arranz E, Fernández-Bañares F, Rosell CM, Rodrigo L, Peña AS, editors. Advances in the Understanding of Gluten Related Pathology and the Evolution of Gluten-Free Foods. Barcelona, Spain: OmniaScience; 2015:27-73.

99. Mobacken H, Kastrup W, Nilsson LA. Incidence and prevalence of dermatitis herpetiformis in western Sweden. Acta Derm Venereol 1984;64:400-404.

100. Gawkrodger DJ, Blackwell JN, Gilmour HM, Rifkind EA, Heading RC, Barnetson RS. Dermatitis herpetiformis: diagnosis, diet and demography. Gut 1984;25:151-157. 
101. Salmi TT, Hervonen K, Kautiainen H, Collin P, Reunala T. Prevalence and incidence of dermatitis herpetiformis: a 40-year prospective study from Finland. Br J Dermatol 2011;165:354-359. doi:10.1111/j.13652133.2011.10385.x

102. Zhang F, Yang B, Lin Y, et al. Dermatitis herpetiformis in China: a report of 22 cases. J Eur Acad Dermatol Venereol 2012;26:903-907. doi:10.1111/j.1468-3083.2011.04204.x

103. Ierardi E, Losurdo G, Piscitelli D, et al. Biological markers for nonceliac gluten sensitivity: a question awaiting for a convincing answer. Gastroenterol Hepatol Bed Bench 2018;11:203-208.

104. Catassi C, Bai JC, Bonaz B, et al. Non-Celiac Gluten sensitivity: the new frontier of gluten related disorders. Nutrients 2013;5:3839-3853. doi: $10.3390 /$ nu5103839

105. Fasano A, Sapone A, Zevallos V, Schuppan D. Nonceliac gluten sensitivity. Gastroenterology 2015;148:1195-1204. doi:10.1053/j. gastro.2014.12.049

106. Elli L, Tomba C, Branchi F, et al. Evidence for the Presence of NonCeliac Gluten Sensitivity in Patients with Functional Gastrointestinal Symptoms: Results from a Multicenter Randomized Double-Blind Placebo-Controlled Gluten Challenge. Nutrients 2016;8:84. doi:10.3390/ nu8020084

107. Lionetti E, Pulvirenti A, Vallorani M, et al. Re-challenge Studies in Non-celiac Gluten Sensitivity: A Systematic Review and Meta-Analysis. Front Physiol 2017;8:621. doi:10.3389/fphys.2017.00621
108. Dey D, Ghosh N, Pandey N, Gupta Bhattacharya S. A hospital-based survey on food allergy in the population of Kolkata, India. Int Arch Allergy Immunol 2014;164:218-221. doi:10.1159/000365629

109. Prescott SL, Pawankar R, Allen KJ, et al. A global survey of changing patterns of food allergy burden in children. World Allergy Organ J 2013;6:21. doi:10.1186/1939-4551-6-21

110. Longo G, Berti I, Burks AW, Krauss B, Barbi E. IgE-mediated food allergy in children. Lancet 2013;382:1656-1664. doi:10.1016/s01406736(13)60309-8

111. Nwaru BI, Hickstein L, Panesar SS, et al; EAACI Food Allergy and Anaphylaxis Guidelines Group. Prevalence of common food allergies in Europe: a systematic review and meta-analysis. Allergy 2014;69:992 1007. doi:10.1111/all.12423

112. Zuidmeer L, Goldhahn K, Rona RJ, et al. The prevalence of plant food allergies: a systematic review. J Allergy Clin Immunol 2008;121:1210 1218.e4. doi: 10.1016/j.jaci.2008.02.019

113. Ostblom E, Lilja G, Pershagen G, van Hage M, Wickman M. Phenotypes of food hypersensitivity and development of allergic diseases during the first 8 years of life. Clin Exp Allergy 2008;38:1325-1332. doi:10.1111/ j.1365-2222.2008.03010.x

114. Sicherer SH, Morrow EH, Sampson HA. Dose-response in doubleblind, placebo-controlled oral food challenges in children with atopic dermatitis. J Allergy Clin Immunol 2000;105:582-586. doi:10.1067/ mai.2000.104941 